\title{
SUITABILITY OF LOCALLY AVAILABLE POTATO VARIETIES FOR CHIPPING
}

\section{C. K. ILLEPERUMA* and N.K. WICKRAMASINGHE}

Department of Food Science \& Technology, Faculty of Agriculture, Universirty of Peradeniya, Peradeniya.

(Received: 24 July 2000; accepted: 06 October 2000)

\begin{abstract}
A study was conducted on eleven locally available potato varieties to investigate their suitability for chipping. The tubers were stored at $80 \% \mathrm{RH}$ and $26 \pm 2{ }^{~} \mathrm{C}$ for three months. Total sugar and dry matter contents of the fresh tubers were analyzed. Potato chips were made before storage and at one and three-month intervals during sturage by slicing into $1 \mathrm{~mm}$ thickness and firying in red palm oil at $190^{\circ} \mathrm{C}$, and the chip colour was measured. The effect of potassium metabisuphite (KMS) and hot water hlanching on the chip colour was tested. The residual sulfur dioxide content of chips was determined.

The total sugar content increased and the diy matter content decreased during storage of the tuhers. The chip lightness as given hy 'L' value showed a negative relationship with total sugars. The colour of chips made from 'Asteric', 'Atlantic', 'Desiree' and 'Red star' was acceptable and was not affected by 3-montin storage. 'Escort', 'Granola', 'Monoliza', 'Prelude', 'Sita', Vivaldi' and 'Aranka' did not produce chips of acceptable colour. Hot water blanching at 90-100 ' $\mathrm{C}$ for $1 \mathrm{~min}$ wit]. $200 \mathrm{ppm}$. KMS improved the chip colour of 'Escorl', Prelude', 'Sita' and 'Vivaldi'. varietics. The residual sulfur dioxide content of these chips was $45 \mathrm{ppm}$. Chip colour of 'Monoliza', 'Granula' and 'Aranka' varieties was not improved by the KMS treatment.
\end{abstract}

Key words: Chip colour; chipping, potato, tutal sugars.

\section{INTRODUCTION}

Potato (Solanum tuberosum L.) cultivation in Sri Lanka is confined mainly to the Badulla and Nuwara Eliya Districts. The extent of cultivation in 1996 was 7925 ha with the production of $1,000,755 \mathrm{Mt} .{ }^{1}$ Both the extent of cultivation and production decreased after $1996^{1}$, probably due to importation of potato tubers mainly from Pakistan and India, after removal of import restrictions. Imported potato tubers are sold at a lower price than that of locally grown potatoes. The price of locally grown potato could not be reduced due to high cost of production. This has caused severe marketing problems to the potato farmers. Use of locally grown potato varieties to produce value-added products such as potato chips, french fries, dehydrated products, potato flour and canned potatoes may increase the net profits of potato cultivation.

The leading potato processors in Sri Lanka use imported varieties for producing potato chips. Small-scale producers use varieties that are available to

\footnotetext{
Corresponding author
} 
them at the time of processing. As a result, the quality of chips varies tremendously, as the processing quality is a function of both physical and chemical factors of the tubers. Apart from the morphological characters such as shape, size and colour of potatoes, the quality of chips depends on the dry matter content, sugars, starch, free amino acids and phenolic compounds of the tubers. ${ }^{2}$ The desirable colour and flavour of fried chips is due to the products of Maillard reaction between reducing sugars and amino acids. ${ }^{3}$ Excessive browning during frying due to high levels of reducing sugars is a major quality defect which produces an unacceptable colour and bitter taste. ${ }^{4}$ Contribution of amino acids to the chip colour is marginal since their concentration is rarely a limiting factor. ${ }^{5}$ Reducing sugar and sucrose contents in Russet Gold potato tubers have shown linear relationships with chip colour.

This study was carried out to determine the suitability of eleven locally grown potato varieties for processing into chips based on total sugar content and chip colour. The changes in total sugar content during storage of tubers and subsequent effect on chip colour were studied. The effect of pre-treatments such as, hot water blanching and use of potassium metabisulphite (KMS) in blanching water on improving chip colour was also tested.

\section{METHODS AND MATERIALS}

Freshly harvested mature potato tubers of eleven varieties namely, 'Aranka' Asteric', 'Atlantic', 'Desiree', 'Escort', 'Granola', 'Monoliza', 'Prelude', 'Red star', 'Sita' and 'Vivaldi' were purchased from the Sita Eliya Agricultural Research Station. The uninfected tubers were selected, washed and cured in $40 \times 60 \mathrm{~cm}$ plastic crates in dark for seven days at $26 \pm 2 " \mathrm{C}$ and $85 \% \mathrm{RH}$ and used to prepare chips.

Tubers of uniform size were hand-peeled, sliced into $1 \mathrm{~mm}$ thickness using a stainless steel slicer (Chiba Company Limited, Japan) and washed thoroughly in water. The excess water was removed by blotting with a clean tissue paper, and the slices were fried in red palm oil at $190^{\circ} \mathrm{C}$. The end point of frying was determined by cessation of bubbling. The chip color was measured by using a colour difference meter (Nippon Denshoku 2000 ZE) and expressed as the 'L' value. The 'L' value of two brands of potato chips available in the market was also determined.

The varieties that produced chips of acceptable colour were stored in perforated polythene bags at $80 \% \mathrm{RH}$ and $26 \pm 2$ "C in dark for three months. The cured potato tubers and the samples withdrawn after one and three months storage were analyzed for dry matter ${ }^{7}$ and total sugars. Sugars from the tubers were extracted $^{8}$, and the total sugar content was determined by the Anthrone method. ${ }^{9}$ Potato chips were made from the samples withdrawn during storage, and chip colour was measured. 
The effect of blanching and inclusion of KMS in blanching water on the chip colour of 'Aranka', 'Escort', 'Granola', 'Monoliza', 'Prelude', 'Sita' and 'Vivaldi' varieties was tested. The tubers were sliced into $1 \mathrm{~mm}$ thickness and subjected to four pre-treatments such as blanching at $90-100^{\circ} \mathrm{C}$ for $1 \mathrm{~min}$. with $50,100,150$ and 200 ppm KMS. Blanching at $90-100^{\circ} \mathrm{C}$ for $1 \mathrm{~min}$. without KMS was used as the control. After each treatment, chips were prepared and the ' $L$ ' value of the chips was measured.

Residual sulfur dioxide of chips was determined according to the methods given in Sri Lanka standard 729:1985.

\section{RESULTS}

The relationship between the total sugar content and the chip colour of eleven potato varieties used in this study is presented in Figure 1. Total sugar content of 'Atlantic', 'Desiree', 'Asteric' and 'Red star' was 0.76, 2.63, 2.59 and $3.08 \mathrm{mg} / \mathrm{g}$ dry weight respectively. These varieties produced chips of acceptable colour, and the ' $\mathrm{L}$ ' value of the chips varied between 43.9 and 48.3 (Figure 1). The variety 'Aranka' contained the highest amount of total sugars $(12.37 \mathrm{mg} / \mathrm{g}$ dry weight) and resulted in chips of the lowest ' $L$ ' value (32.3).

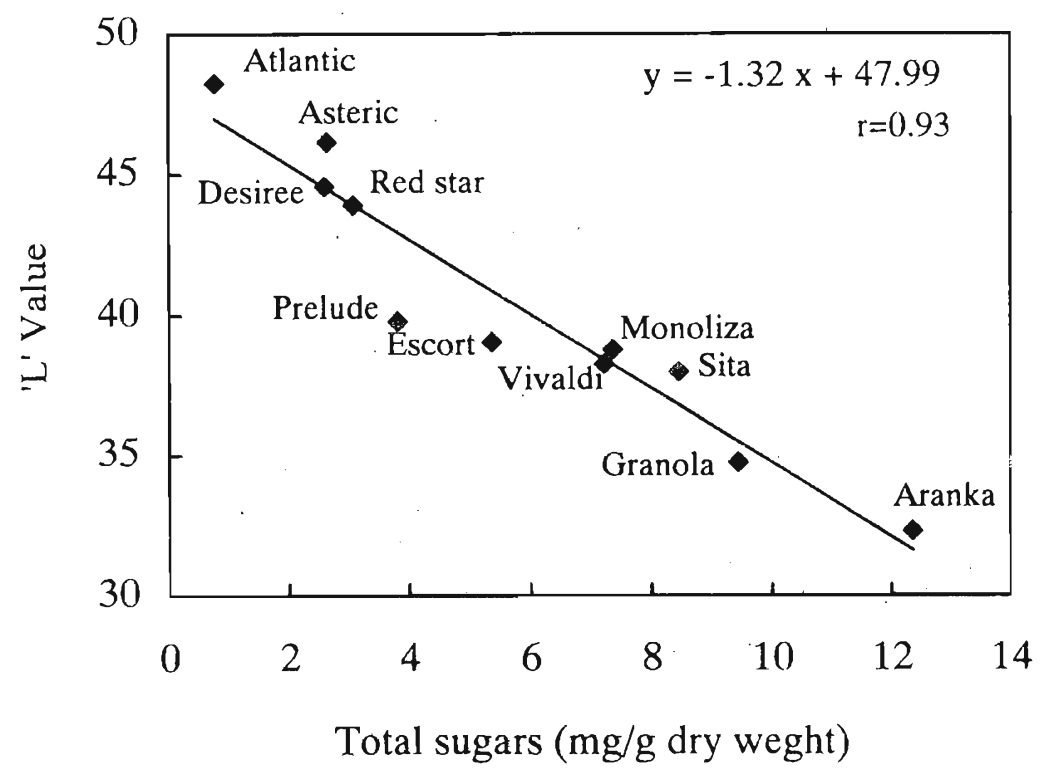

Figure 1: Relationship between the total sugar content of different potato varieties and the chip colour. 
Dry matter contents of the eleven potato varieties are presented in Table 1 , which varied between $17.7 \%$ ('Vivaldi') and $30.2 \%$ ('Atlantic'). The dry matter: content of 'Atlantic', 'Desiree', 'Asteric' and 'Red star' decreased during storage at $80 \% \mathrm{RH}$ and $26 \pm 2{ }^{\circ} \mathrm{C}$ for three months (Table 1 ).

Table 1: The dry matter content of potato tubers after curing and during storage at $80 \% \mathrm{RH}$ and $26 \pm 2^{\circ} \mathrm{C}$

\begin{tabular}{lccc}
\hline Variety & \multicolumn{3}{c}{ Dry matter content (\%) } \\
\cline { 2 - 4 } & Cured tubers & One month & Three months \\
\hline Atlantic & $30.2 \pm 1.1$ & $28.8 \pm 1.0$ & $25.6 \pm 0.7$ \\
Asteric & $24.6 \pm 1.0$ & $22.5 \pm 1.3$ & $19.3 \pm 0.9$ \\
Desiree & $22.3 \pm 0.8$ & $20.2 \pm 1.1$ & $18.9 \pm 0.6$ \\
Red Star & $24.6 \pm 0.9$ & $23.7 \pm 0.9$ & $21.3 \pm 0.8$ \\
Prelude & $18.2 \pm 1.6$ & n.d & n.d \\
Escort & $22.2 \pm 1.2$ & n.d & n.d \\
Vivaldi & $17.7 \pm 1.3$ & n.d & n.d \\
Sita & $22.6 \pm 0.9$ & n.d & n.d \\
Monoliza & $22.1 \pm 0.9$ & n.d & n.d \\
Granola & $22.2 \pm 0.7$ & n.d & n.d \\
Aranka & $21.7 \pm 0.8$ & n.d & n.d \\
\hline
\end{tabular}

Data are presented as mean \pm standard deviation of three replicates. n.cl.- not determined.

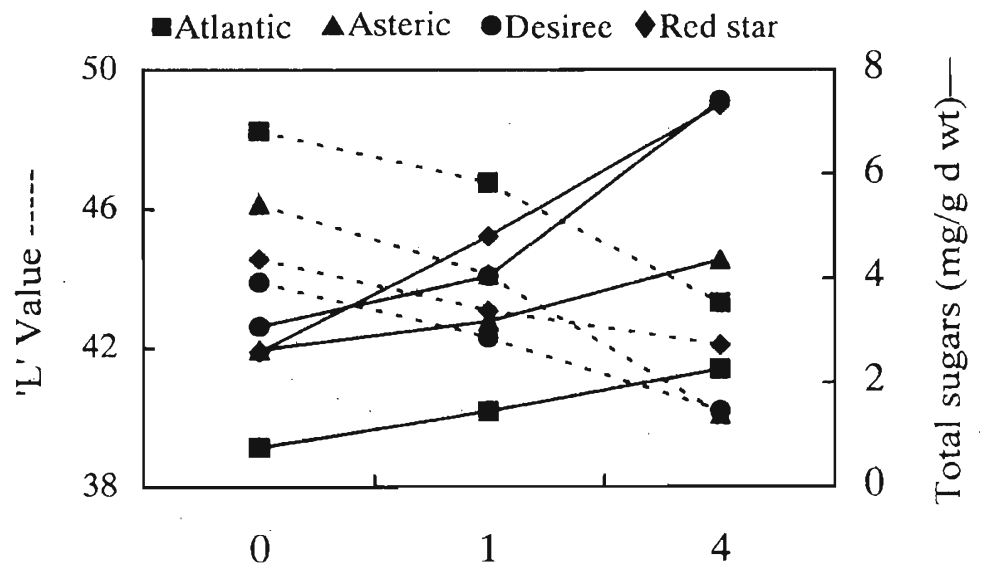

Storage period (months)

Figure 2: Colour of chips as affected by changes in the total sugar content during storage of potato tubers. 
The relationship between the total sugar content and the chip colour of 'Atlantic', 'Desiree', 'Asteric' and 'Red star' during storage at $80 \% \mathrm{RH}$ and $26 \pm 2^{\circ} \mathrm{C}$ for three months is presented in Figure 2. With the increase in the total sugar content of these varieties, the ' $L$ ' value of the chips decreased (Figure 2).

The effect of blanching and inclusion of KMS in blanching water on the chip colour of 'Aranka', 'Escort', 'Granola', 'Monoliza', 'Prelude', 'Sita' and 'Vivaldi' is presented in Table 2. With the increase in concentration of KMS in the blanching water, the ' $L$ ' value of fried chips increased (Table 2 ).

Table 2: Effect of potassium metabisuphite (KMS) in blanching water on chip colour ('L' value)

\begin{tabular}{lccccc}
\hline Variety & \multicolumn{5}{c}{ KMS concentration } \\
\cline { 2 - 6 } & $0 \mathrm{ppm}$ & $50 \mathrm{ppm}$ & $100 \mathrm{ppm}$ & $150 \mathrm{ppm}$ & $200 \mathrm{ppm}$ \\
\hline Prelude & $40.4 \pm 0.2$ & $40.6 \pm 0.3$ & $40.9 \pm 0.1$ & $41.2 \pm 0.3$ & $46.8 \pm 0.2$ \\
Escort & $39.4 \pm 0.1$ & $39.7 \pm 0.2$ & $39.9 \pm 0.2$ & $41.6 \pm 0.2$ & $46.7 \pm 0.3$ \\
Vivaldi & $38.7 \pm 0.2$ & $38.9 \pm 0.3$ & $39.5 \pm 0.2$ & $39.9 \pm 0.1$ & $43.5 \pm 0.2$ \\
Sita & $38.9 \pm 0.3$ & $39.2 \pm 0.2$ & $39.5 \pm 0.3$ & $39.8 \pm 0.1$ & $44.1 \pm 0.2$ \\
Monoliza & $38.0 \pm 0.2$ & $38.3 \pm 0.2$ & $38.6 \pm 0.3$ & $38.6 \pm 0.2$ & $38.8 \pm 0.3$ \\
Granola & $34.7 \pm 0.2$ & $34.8 \pm 0.3$ & $34.9 \pm 0.2$ & $35.2 \pm 0.4$ & $35.8 \pm 0.2$ \\
Aranka & $32.3 \pm 0.3$ & $32.5 \pm 0.1$ & $32.8 \pm 0.2$ & $32.8 \pm 0.2$ & $32.9 \pm 0.4$ \\
\hline
\end{tabular}

Data are presented as mean \pm standard deviation of three replicates.

\section{DISCUSSION}

Colour is an important criterion for marketing potato chips, and the maintenance of the desired colour is the major problem associated with the chipping industry. ${ }^{10}$ There are inherent differences among varieties with respect to chip colour ${ }^{11}$, as indicated by the ' $L$ ' values varying from 32.2 to 48.3 for chips processed from the eleven potato varieties used in this study (Figure 1). The processors prefer varieties that are best suited to produce light colour chips. The reducing sugar levels are used to predict the suitability of potato tubers for chip processing as they are often responsible for colour development. ${ }^{4,5}$ It is well established that sucrose, fructose and glucose comprise the major soluble sugars of white potatoes. ${ }^{12,13}$ Sucrose, a non-reducing sugar, can also be important in chip colour development through hydrolysis during frying. ${ }^{14,15,16}$ Thus, the total sugar content could also be a good indicator of the suitability of potato tubers for chipping, as indicated by the negative correlation ( $r=0.93$ ) observed between the total sugar content and the 
chip colour of eleven potato varieties used in this study (Figure 1). This is in agreement with the work of Rodriguez-Saona et al. ${ }^{6}$ where decrease in chip lightness with increase in both reducing sugars and sucrose content was reported. All the varieties with the total sugar content of more than $3.1 \mathrm{mg} / \mathrm{g}$ dry weight, produced chips of dark colour as indicated by the ' $L$ ' values varying between 39.8 and 32.2 (Figure 1). These values were lower than that of the ' $L$ ' values of two commercial brands of local and imported chips, which were 40.6 and 43.7 respectively.

A large variation in the dry matter content of Indian potato varieties is reported. ${ }^{2}$ Potatoes with high dry matter content are considered suitable for chips ${ }^{17}$ as the dry matter content is associated with mealiness, crispness and reduced oil uptake in the fried chips. ${ }^{18}$ Three Indian potato varieties namely 'Kufri Bahar', 'Kufri Badshai' and 'Kufri Jyoti' are reported to be unacceptable for chipping as the dry matter content is less than $17.8 \% .^{2}$ Based on this fact the variety 'Vivaldi' which contains $17.7 \%$ dry matter (Table 1 ) may not be suitable for chipping.

The total sugar content of 'Atlantic', 'Desiree', 'Asteric' and 'Red star' varieties which produced chips of acceptable colour increased (Figure 2) and the dry matter content decreased (Table 1 ) during storage at $80 \% \mathrm{RH}$ and $26 \pm 2{ }^{\circ} \mathrm{C}$ for three months (Figure 2). This is probably due to initiation of sprouting, which was evident in this study. With the increase in the total sugar content of these varieties, the ' $L$ ' value of the chips decreased (Figure 2). When the 'L' values were above 39.8 , the colour was acceptable. However, measures need to be taken to prevent sprouting of the tubers, thereby minimizing changes in dry matter and total sugar content during storage, as the quality of chips may be affected.

Hot water blanching has been reported to be successful in removing glucose from potato slices of 'Accent' cultivar. ${ }^{19}$ Improvement of chip colour by blanching of 'K. Jyoti' variety has also been reported. ${ }^{20}$ However, in this study, hot water blanching at 90-100 'C for 1 min was not effective in improving the chip colour of 'Prelude', 'Monoliza', 'Vivaldi', 'Escort', 'Aranka', 'Granola' and 'Sita' varieties (Table 2). This is probably due to their high sugar content.

Sulphites are widely used to inhibit Maillard browning. ${ }^{21} \mathrm{KMS}$ is a permitted preservative in foods in Sri Lanka ${ }^{22}$. With the increase in concentration of KMS in the blanching water, the ' $L$ ' value of fried chips increased (Table 2). KMS at a concentration of $50 \mathrm{ppm}$ was reported to be effective in improving the chip colour of 'Kufri Chandramukhi' variety. ${ }^{23}$ However, in our study, the optimum concentration of KMS required to improve the chip colour of 'Prelude', 'Sita', 'Vivaldi' and 'Escort' varieties was $200 \mathrm{ppm}$. Even at this KMS concentration, the chip colour of 'Aranka', 'Granola' and 'Monoliza' varieties was not acceptable.

The maximum allowable level of the residual sulphur dioxide in crystallized or glaze fruits is 100 ppm..$^{22}$ As the residual sulphur dioxide content of the fried chips 
was $45 \mathrm{ppm}$, hot water blanching at $90-100^{\circ} \mathrm{C}$ for 1 min with $200 \mathrm{ppm}$ KMS could be recommended to improve the chip colour of 'Prelude', 'Sita', 'Vivaldi' and 'Escort' varieties.

'Asteric', 'Atlantic', 'Desiree' and 'Red star' varieties could be recommended for chipping. The chip colour of the varieties 'Escort', 'Prelude', 'Sita' and 'Vivaldi' could be improved by hot water blanching with 200 ppm KMS. 'Monoliza', 'Granola' and 'Aranka' are not suitable for chipping.

\section{Acknowledgment}

The authors thank J.I.LB. Ratnayake of the Faculty of Agriculture, University of Peradeniya for his help in statistical analyses and A.C.M. Mazeem of the Agriculture Research Station, Sita Eliya for providing potato tubers. The study was supported by a grant from the University of Peradeniya (RG/98/09/Ag).

\section{References}

1. Agricultural Statistics (1998). Department of Census and Statistics, Colombo.

2. Marwaha R.S. (1999). Chipping quality and related processing characteristics of Indian potato varieties grown under short dark conditions. Journal of Food Science and. Technology 36: 157-159.

3. Fuller T.J. \& Huges J.C. (1984). Factors influencing the relationships between reducing sugars and fry colour of potato tubers cv. 'Record'. Journal of Food. Technology 19:455-467.

4. Roe M.A., Faulks R.M. \& Belsten J.L. (1990). Role of reducing sugars and amino acids in fry colour of chips from potatoes grown under different nitrogen regimes. Journal of Science, Food \& Agriculture 52: 207-214.

5. Marquez G. \& Anon M.C. (1986). Influence of reducing sugars and amino acids in the colour development of fried potatoes. Journal of Food Science 51:157-160.

6. Rodriguez-Saona L.E., Wrolstad R.E. \& Pereira C. (1997). Modelling the contribution of sugars, ascorbic acid, chlorogenic acid and amino acids to non-enzymatic browning of potato chips. Journal of Food Science 62:1001-1004.

7. AOAC. (1990). Official Methods of Analysis. Vol. 2. pp 69-81. Association of Official Analytical Chemists, Inc, Virginia. 
8. Illeperuma C., Schlimme D. \& Solomos S. (1998). Changes in sugars and activities of sucrose phosphate synthase, sucrose synthase, and invertase during potato tuber (Russet Burbank) reconditioning at $10^{\prime \prime} \mathrm{C}$ in air and 2.53 kPa oxygen after storage for 28 days at 1 "C. Journal of the American Society of Horticultural Science 123:311-316.

9. Khoshkhoo N., Hedin A. \& McCarty J.C. (1994). Free sugars in root-knot nematode susceptible and resistant cotton plant roots and leaves. Journal of Agriculture \& Food Chemistry 42:366-368.

10. Clegg M.D. \& Chapman H.W. (1962). Sucrose content of tubers and discolouration of chips from early harvested potatoes. American Potato Journal 39: 212-216.

11. Miller R.A., Harrington J.D. \& Kuhn C.D. (1975). Effects of variety and harvest date on tuber sugars and chip colour. American Potato Journal 12: $379-386$.

12. Schiwimmer S., Bevenue A., Weston W.J. \& Potter A.A. (1954). Survey of major and minor sugar and starch components of the white potato. Journal of Agriculture \& Food Chemistry 2:1284-1289.

13. Isherwood F.A. (1973). Starch-sugar interconversion in Solanum tuberrosum. Phytochemistry 12: 2579-2591.

14. Leszkowait M.J., Baricello V., Yada R.Y., Coffin R.H., Lougheed E.C. \& Stanley D.W. (1990). Contribution of sucrose to non-enzymatic browning in potato chips. Journal of Food Science 55: 281-282.

15. Mazza G. (1983). Correlation between quality parameters of potatoes during growth and long-term storage. American Potato Journal 60: 145-159.

16. Shallenberger R.S., Smith O. \& Treadway R.H. (1959). Role of sugars in the browning reaction in potato chips. Journal of Agriculture \& Food Chemistry 7: 274-277.

17. Howard H.W. (1978). The production of new varieties, In: The potato crop. The scientific basis for improvement (Ed. P.M. Harris) pp 607-646. Chapman and Hall, New York.

18. Grewal S.S. \& Uppal D.S. (1989). Effect of dry matter and specific gravity on yield, colour and oil content of potato chips. Indian Food Packer 43:17-20. 
19. Mate J.I., Quartaert C., Meerdink G. \& van'tRite K. (1998). Effect of blanching on structural quality of dried potato slices. Journal of Agriculture \& Food Chemistry 46:676-681.

20. Sandhu K.S. \& Kaur B. (1992). Effect of storage and pre-treatments on potato chip colour quality. Journal of Food Science and Technology 29: 113-114.

21. Whistler R.L. \& Daniel J.R. (1985). Carbohydrates. In: Food chemistry (Ed. O.R. Fennema )pp. 65- 138. Marcel Dekker, Inc. New York and Basel.

22. The Gazette of the Democratic Socialist Republic of Sri Lanka (extraordinary), No: 615/11-1990.06.19. Food (Preservatives) Regulations.

23. Waghmare N.V., Kotecha P.M. \& Kadam S.S. (1999). Effects of pre-treatments, storage of potato and antioxidants on quality of potato chips prepared from cultivars grown in Western Maharashtra. Journal of Food Science and Technology 36: 49-51. 